\title{
Penggunaan Media Audio Visual Untuk Meningkatkan Hasil Belajar Siswa pada Mata Pelajaran Mulok Materi Upacara Adat Daerah Bima di SMAN 4 Kota Bima Kelas X IPS 4 Semester Ganjil Tahun Pelajaran 2020/2021
}

\author{
Sitti Kalisom \\ SMA Negeri 4 Kota Bima, Kota Bima, Indonesia \\ *Coresponding Author : sitikalisom066@gmail.com \\ Dikirim: 19-08-2021; Direvisi: 24-10-2021; Diterima: 25-10-2021
}

\begin{abstract}
Abstrak: Hasil refleksi penelitian pra-sklus menunjukan, rendahnya hasil belajar siswa ini ditunjukkan dengan indikator rata-rata yakni yakni 64.00, dengan ketuntasan klasikal $68.00 \%$. Hal ini masih dibawah indikator kinerja yang ditentukan rata-rata $\geq 70.00$ dengan ketuntasan klasikal $\geq 83.00 \%$. Perumusan masalah dalam penelitian ini adalah: "Bagaimana penggunaan audio visual berbasis untuk meningkatkan hasil belajar siswa pada pembelajaran Mulok materi Upacara Adat Daerah Bima di Kelas X IPS-4 Semester I SMAN 4 Kota Bima tahun pelajaran 2020/2021?". Tujuan Penelitian Perbaikan Pembelajaran: 1. Mendeskripsikan penggunaan audio visual berbasis untuk meningkatkan hasil belajar siswa pada pembelajaran Mulok materi Upacara Adat Daerah Bima di Kelas X IPS-4 Semester I SMAN 4 Kota Bima tahun pelajaran 2020/2021?. 2. Menganalisis dampak penggunaan audio visual berbasis untuk meningkatkan hasil belajar siswa pada pembelajaran Mulok materi Upacara Adat Daerah Bima di Kelas X IPS-4 Semester I SMAN 4 Kota Bima tahun pelajaran 2020/2021?. Subyek penelitian perbaikan adalah siswa Kelas X IPS-4 Semester I SMAN 4 Kota Bima dengan jumlah siswa 31 terdiri dari 15 orang laki-laki dan 16 orang perempuan. Perbaikan dilaksanakan dalam 2 (dua) siklus. Siklus I dari tanggal 13 Agustus 2020 sampai dengan 23 September 2020 dan siklus II dilaksanakan tanggal 02 Oktober 2020 sampai dengan 15 November 2020. Teknik pengumpulan data meliputi pengamatan, dokumen dan tes. Peningkatan hasil belajar siswa ini dapat dibandingkan dari hasil tes praperbaikan. Hasil pos tes siklus I diatas menunjukkan bahwa hasil belajar siswa Mulok ratarata $68.12(+4.12)$, Persentase ketuntasan $73.00 \%(+5.00)$, Skor kinerja guru, kompetensi guru dalam perencanaan (APKG I) siklus I $89.45(+0.45)$ dan skor kinerja guru dalam pelaksanaan pembelajaran yang mendidik (APKG II) siklus I 88.45 (+0.45). Dengan demikian dari sisi kinerja guru siklus I belum mencapai indikator kinerja yang ditetapkan yakni APKG I dan APKG II yakni $\geq 90.00$. Hasil pos tes siklus II menunjukkan bahwa hasil belajar siswa Mulok rata-rata $77.00(+8.88)$ dengan persentase ketuntasan $85.00 \%(+12.00)$. Dengan demikian pada siklus II ini telah berhasil mencapai indikator yang ditetapkan yakni rata-rata $\geq 70.00$ dan persentase ketuntasan $\geq 83.00 \%$. Dari sisi prestasi belajar siklus II (kedua) telah berhasil. Skor kinerja guru menunjukkan bahwa skor ketuntasan guru dalam perencanaan pembelajaran siklus II APKG I $91.00(+1.55)$ dan skor kinerja guru dalam pelaksanaan pembelajaran APKG II siklus II 90.77 (+2.32). Dengan perbaikan proses pembelajaran berhasil memenuhi indikator kinerja yang ditetapkan yakni perencanaan APKG I dan pelaksanaan APKG II yakni $\geq 90.00$. Peningkatkan prestasi belajar siswa, disebabkan oleh peningkatan aktivitas, interaksi guru dan siswa dalam proses pembelajaran di kelas dengan penggunaan media audio visual. Dengan demikian setelah pelaksanaan perbaikan pembelajaran sampai siklus II, telah mencapai indikator kinerja yang ditetapkan, dan penelitian dianggap telah berhasil.
\end{abstract}

Kata Kunci: Hasil belajar; penggunaan media audio visual; pembelajaran mulok 


\begin{abstract}
The results of the reflection of the pre-cycle research show that the low student learning outcomes are indicated by the average indicator, namely 64.00, with a classical completeness of $68.00 \%$. This is still below the performance indicator determined by an average of 70.00 with a classical completeness of $83.00 \%$. The formulation of the problem in this study is: "How is the use of audio-visual based to improve student learning outcomes in Mulok learning material for the Bima Regional Traditional Ceremony in Class X IPS-4 Semester I SMAN 4 Bima City in the 2020/2021 academic year?". Learning Improvement Research Objectives: 1. To describe the use of audio-visual based to improve student learning outcomes in Mulok learning materials for the Bima Regional Traditional Ceremony in Class X IPS-4 Semester I SMAN 4 Bima City in the 2020/2021 academic year?. 2. Analyzing the impact of using audio-visual-based to improve student learning outcomes in Mulok learning materials for the Bima Regional Traditional Ceremony in Class X IPS-4 Semester I SMAN 4 Bima City for the 2020/2021 academic year?. The subjects of the improvement research were students of Class X IPS-4 Semester I of SMAN 4 Kota Bima with a total of 31 students consisting of 15 boys and 16 girls. Repairs are carried out in 2 (two) cycles. Cycle I from August 13, 2020 to September 23, 2020 and cycle II was held from October 2, 2020 to November 15, 2020. Data collection techniques included observations, documents and tests. This improvement in student learning outcomes can be compared from the results of the pre-improvement test. The results of the post-test cycle I above show that the student learning outcomes of Mulok are on average $68.12(+4.12)$, the percentage of completeness is $73.00 \%(+5.00)$, teacher performance scores, teacher competence in planning (APKG I) cycle I $89.45(+0.45)$ and teacher performance score in the implementation of educational learning (APKG II) cycle I $88.45(+0.45)$. Thus, in terms of teacher performance in cycle I, the performance indicators have not yet reached the set performance indicators, namely APKG I and APKG II, namely 90.00. The results of the post-test cycle II showed that Mulok's student learning outcomes averaged $77.00(+8.88)$ with a completeness percentage of $85.00 \%(+12.00)$. Thus, in the second cycle, it has succeeded in achieving the specified indicators, namely an average of 70.00 and a percentage of completeness $83.00 \%$. In terms of learning achievement, cycle II (second) has been successful. The teacher's performance score shows that the teacher's mastery score in learning planning cycle II APKG I is $91.00(+1.55)$ and the teacher's performance score in the implementation of learning APKG II cycle II is 90.77 (+2.32). By improving the learning process, the performance indicators have been met, namely the planning of APKG I and the implementation of APKG II, which is 90.00. The increase in student achievement was caused by an increase in activities, teacher and student interactions in the learning process in the classroom using audio-visual media. Thus, after the implementation of learning improvements up to cycle II, the performance indicators have been achieved, and the research is considered successful.
\end{abstract}

Keywords: learning outcomes; use of audio-visual media; great learning

\title{
PENDAHULUAN
}

Mencapai hasil belajar yang tinggi, anak-anak yang cerdas tentu menjadi tujuan bagi setiap guru dalam melaksanakan proses pembelajaran. Namun demikian dalam kenyataannya di kelas, upaya mewujudkan hal tersebut bukanlah pekerjaan yang mudah. Untuk dapat mencapai hal tersebut salah satunya adalah dengan melaksanakan proses pembelajaran yang menarik. Guru perlu mengkodisikan siswa sehingga siswa melaksanakan aktivitas belajar sesuai yang diinginkan. Slameto (2010: 36) berpendapat mengenai proses belajar mengajar bahwa dalam proses belajar mengajar, guru perlu menimbulkan aktivitas siswa dalam berpikir maupun berbuat. Aktivitas yang dilakukan siswa dalam proses pembelajaran tersebut 
akan meninggalkan kesan. Siswa tidak akan menghilangkan kesan tersebut begitu saja, tetapi dipikirkan, diolah, kemudian dikeluarkan lagi dalam bentuk yang berbeda.

Aktivitas belajar yang tinggi dapat tercipta apabila pembelajaran menarik sehingga dapat mengurangi atau bahkan menghilangkan beban psikologis siswa. Hal ini tentunya akan mengefektifkan dan mengesienkan aktivitas pembelajaran di kelas. Pembelajaran yang efektif dan efisien membutuhkan kerja sama yang kompak antara guru dan siswa. Dalam proses pembelajaran harus terjadi interaksi yang intensi antar komponen sistem pembelajaran guru, siswa, materi pembelajaran dan lingkungan (Suyanto, 2013).

Hal tersebut sejalan dengan PP No. 19 Tahun 2005 pasal 19 ayat 1 tentang Standar Nasional Pendidian, pembelajaran pada satuan pendidikan diselenggarakan secara interaktif, inspiratif, menyenangkan, menantang, memotivasi peserta didik untuk berpartisipasi aktif, serta memberikan ruang yang cukup bagi prakarsa, kreativitas, dan kemandirian sesuai dengan bakat, minat, dan perkembangan fisik serta psikologis peserta didik. Lebih jelas dalam Permendikbud Nomor 22 Tahun 2016 tentang Standar Proses menyebutkan proses pembelajaran pada satuan pendidikan diselenggarakan secara interaktif, inspiratif, menyenangkan, menantang, memotivasi peserta didik untuk berpartisipasi aktif, serta memberikan ruang yang cukup bagi prakarsa, kreativitas, dan kemandirian sesuai dengan bakat, minat, danperkembangan fisik serta psikologis peserta didik. Untuk itu setiap satuan pendidikan melakukan perencanaan pembelajaran, pelaksanaan proses pembelajaran serta penilaian proses pembelajaran untuk meningkatkan efisiensi dan efektivitas ketercapaian kompetensi lulusan. Mewujudkan aktivitas pembelajaran yang interaktif dan menyenangkan bukanlah hal yang mudah bagi guru. Hal ini peneliti alami pada pra-siklus sebelum pelaksanaan perbaikan pembelajaran.

Pada pra-siklus, di Kelas X IPS-4 semester I SMAN 4 Kota Bima pada pembelajaran Mulok materi Upacara Adat Daerah Bima peneliti telah berusaha menerapkan pembelajaran dengan mengacu pada kurikulum yang berlaku yakni Kurikulum 2013 dengan pendekatan saintifik, RPP telah peneliti susun dengan cermat akan tetapi aktivitas belajar siswa rendah.Peneliti menggunakan metode ceramah dan tanya jawab tanpa media pembelajaran Pembelajarn berjalan siswa pasif dan suasana pembelajaran kurang membosankan bagi siswa. Siswa diam, tidak banyak memberikan respon ketika proses pembelajaran berlangsung. Hal ini tentu jauh dari apa yang dihajatkan dalam Kurikulum 2013 lebih khusus pada Standar Proses.

Dalam proses pembelajaran di Kelas X IPS-4 semester I SMAN 4 Kota Bima pada pembelajaran Mulok materi Upacara Adat Daerah Bima, peneliti telah berusaha menyajikan materi pembelajaran semenarik mungkin, dengan sungguh-sungguh menguasai materi pembelajaran, menyiapkan materi pembelajaran serta pengaturan dan pengelolaan kelas sebaik mungkin.

Secara umum pembelajaran berjalan tertib, rapi, para siswa mengikuti proses pembelajaran dari awal sampai akhir dengan baik. Akan tetapi, aktivtias belajar, interaksi yang terjadi selama proses pembelajaran tersebut cenderung satu arah, yakni guru kepada siswa, sementara pertanyaan-pertanyaan yang peneliti tunggutunggu selama proses pembelajaran tidak terjadi. Pada awalnya peneliti merasa optimis bahwa pembelajaran akan berhasil, akan tetapi pada saat dilakukan pos tes, 
hasilnya tidak sesuai yang diharapkan. Siswa tertib, diam selama proses pembelajaran ternyata tidak identik dengan keberhasilan proses pembelajaran. Dengan menggunakan instrumen kinerja guru yang diukur dengan APKG I dan APKG II rendah. Nilai APKG I, untuk perencanaan pembelajaran 89.00 dan APKG II, untuk pelaksanaan pembelajaran 88.00. Nilai ini masih dibawah indikator kinerja yang ditetapkan yakni APKG I, untuk perencanaan pembelajaran $\geq 90.00$ dan APKG II, untuk pelaksanaan pembelajaran $\geq 90.00$. Dari prestasi belajar siswapun rendah, hal ini ditunjukkan dengan rendahnya rata-rata nilai formatif tes siswa yakni 64.00, dengan ketuntasan klasikal $68.00 \%$. Hal ini masih dibawah indikator kinerja yang ditentukan rata-rata $\geq 70.00$ adalah ketuntasan klasikal $\geq 83.00 \%$.

Dari data hasil proses pembelajaran pra-perbaikan tersebut peneliti mengidentifikasi permasalahan pembelajaran yang telah dilaksanakan. Hasil identifikasi masalah menunjukkan bahwa: a) meskipun guru telah melaksanakan pembelajaran dengan baik, siswa tertib, akan tetapi siswa tidak turut aktif selama proses pembelajaran; b) tidak aktifnya siswa karena guru menggunakan model pembelajaran sesuai tetapi penerapannya tidak untuk kondisi siswa; c) guru tidak menggunakan media pembelajaran yang dibutuhkan dan diinginkan siswa; dan d) dari rangkaian permasalahan tersebut berdapak pada, hasil belajar siswa rendah.

Dari permasalahan keempat tersebut, terdapat 3 (tiga) permasalahan penting yang akan diatasi yaitu permasalahan: (a) tidak aktifnya siswa karena guru menggunakan metode pembelajaran yang tidak sesuai dengan materi pembelaajaran (b) guru tidak menggunakan media pembelajaran yang dibutuhkan dan diinginkan siswa dan (c) hasil belajar siswa rendah.

Permasalahan pada pra siklus tersebut apabila tidak segera diatasi maka dikhawatirkan akan berdampak lebih buruk lagi bagi siswa, yaitu semakin rendahnya prestasi belaajar siswa dan semakin rendahnya kualitas pembelajaran. Dari belajar referensi tentang Penelitian Tindakan kelas (PTK) demikian pula dengan berdiskusi bersama kolega, senior guru lain, untuk mengatasi permasalahan pembelajaran yang peneliti hadapi yang akan diterapkan dalam praktik perbaikan pembelajaran dengan langkah-langkah Penelitian Tindakan Kelas.

Pemiihan metode pembelajan yang tidak tepat, tidak adanya media pembelajaran menjadi kajian utama peneliti sebelum melakukan perbaikan pembelajaran. Salah satu yang menarik perhatian anak-anak adalah gambar dan audio visual, video kotekstual. Dengan gambar-gambar dan video yang dikaitkan pembelajaran Mulok materi Upacara Adat Daerah Bima di Kelas X IPS-4 Semester I SMAN 4 Kota Bima tahun pelajaran 2020/2021, diharapkan pembelajaran akan lebih menarik, menyenangkan, merangsang siswa aktif sekaligus meningkatkan hasil belajarnya.

Dengan penggunaan kombinasi media audio visual tersebut diharapkan permasalahan pembelajaran akan dapat teratasi, sekaligus meningkatkan hasil belajar siswa. Media audio visual sebagaimana dikemukanan oleh Arsyad (2011: 49-50) memiliki tidak kurang dari 7 (tujuh kelebihan) sebagai media pembelajaran. Yang menjadi pertimbangan penting lagi adalah media audio visual berupa video yang berkaitan dengan pembelajaran Mulok materi Upacara Adat Daerah Bima dapat diperoleh dengan lengkap di internet, dengan demikian membantu peneliti dalam perencanaan dan pelaksanaan pembelajaran. 


\section{KAJIAN TEORI}

\section{Hakikat Belajar}

Belajar adalah perkembangan yang berasal dari latihan dan usaha (Soeparwoto dkk 2007: 34). Belajar dapat terjadi melalui dua cara yaitu imitasi dan identifikasi. Imitasi artinya individu meniru yang dilakukan orang lain. Sedangkan identifikasi artinya individu menerima sikap, nilai, motivasi, dan perilaku orang yang dihormati atau dicintai. Gagne dan Berliner dalam Anni dkk (2007:2) mendefinisikan belajar merupakan proses dimana suatu organisme mengubah perilakunya karena hasil dari pengalaman.

Pengertian belajar menurut Slameto (2010: 2) adalah suatu proses usaha yang dilakukan seseorang untuk memperoleh suatu perubahan tingkah laku yang baru secara keseluruhan, sebagai hasil pengalamannya sendiri dalam interaksi dengan lingkungannya. Berdasarkan beberapa pengertian belajar, maka dapat disimpulkan bahwa belajar merupakan suatu proses perubahan sikap dan tingkah laku yang bersifat permanen yang disebabkan karena adanya pengaruh pengalaman dan lingkungan.

\section{Hakikat Aktivitas Belajar}

Menurut Sardiman dalam Saminanto (2010: 97) aktivitas belajar adalah keaktifan yang bersifat fisik maupun mental. Dalam proses pembelajaran keduanya harus saling menunjang agar diperoleh hasil belajar yang optimal.

Menurut Poerwadarminta dalam Yusfy (2011), aktivitas adalah kegiatan, sehingga aktivitas belajar adalah kegiatan-kegiatan siswa yang menunjang keberhasilan belajar. Slameto (2010: 36) berpendapat mengenai proses belajar mengajar bahwa dalam proses belajar mengajar, guru perlu menimbulkan aktivitas siswa dalam berpikir maupun berbuat. Aktivitas yang dilakukan siswa dalam proses pembelajaran tersebut akan meninggalkan kesan. Siswa tidak akan menghilangkan kesan tersebut begitu saja, tetapi dipikirkan, diolah, kemudian dikeluarkan lagi dalam bentuk yang berbeda.

Berdasarkan beberapa pengertian aktivitas yang telah dipaparkan, maka peneliti dapat menyimpulkan bahwa aktivitas belajar adalah segala kegiatan yang dilakukan siswa selama proses pembelajaran baik yang bersifat fisik maupun mental dan akan berpengaruh pada hasil belajar. Jadi, hasil belajar yang diperoleh siswa sangat bergantung pada bagaimana aktivitas belajar yang dilakukan selama pembelajaran.

\section{Hakikat Hasil belajar}

Hasil belajar merupakan perubahan perilaku yang diperoleh pembelajar setelah mengalami aktivitas belajar (Anni dkk 2007: 5). Menurut Suprijono (2011:5), hasil belajar adalah pola-pola perbuatan, nilai-nilai, pengertianpengertian, sikap-sikap, apresiasi, dan keterampilan. Hasil belajar menurut Bloom dalam Rifa'i dan Anni (2009: 86) digolongkan menjadi tiga domain, yaitu domain kognitif, afektif dan psikomotor. Domain kognitif berkenaan dengan pengembangan kemampuan otak dan penalaran siswa. Domain afektif berkenaan dengan sikap dan nilai. Domain psikomotor tampak dalam bentuk keterampilan dan kemampuan siswa dalam bertindak. 
Menurut Gagne dan Briggs dalam Anni dkk (2007:12) mengklasifikasikan hasil belajar dalam lima kategori, yaitu: (1) kemahiran intelektual; (2) strategi kognitif ; (3) informasi verbal ; (4) kemahiran motorik ; dan (5) sikap. Berdasarkan paparan mengenai pengertian hasil belajar, maka dapat disimpulkan bahwa hasil belajar merupakan kemampuan yang dimiliki seseorang setelah mengalami proses belajar, baik yang bersifat langsung maupun tidak langsung (dampak pengiring). Hasil belajar akan lebih bermakna apabila proses pelaksanaannya menyenangkan dan terjadi penguatan.

\section{Hakikat Pembelajaran}

Undang-Undang No 20 tahun 2003 tentang Sistem Pendidikan Nasional Bab I Pasal 1 ayat 20 menjelaskan bahwa pengertian pembelajaran adalah proses interaksi peserta didik dengan pendidik dan sumber belajar pada suatu lingkungan belajar. Pembelajaran menurut Briggs dalam Sugandi (2007: 9) adalah seperangkat peristiwa yang mempengaruhi si belajar sedemikian rupa, sehingga memperoleh kemudahan dalam berinteraksi berikutnya dengan lingkungan.

Menurut Isjoni (2010:11) pembelajaran pada dasarnya merupakan upaya pendidik untuk membantu peserta didik melakukan kegiatan belajar. Menurut Siddiq dkk (2009: 1-9) pembelajaran adalah suatu upaya yang dilakukan oleh seseorang (guru atau yang lain) untuk membelajarkan siswa yang belajar. Pada pendidikan formal (sekolah), pembelajaran merupakan tugas yang dibebankan kepada guru, karena guru merupakan tenaga profesional yang dipersiapkan untuk itu.

Dari beberapa pengertian pembelajaran, maka peneliti dapat menyimpulkan pengertian pembelajaran adalah seperangkat peristiwa berupa interaksi siswa dengan pendidik dan sumber belajar lainnya untuk mencapai hasil belajar yang telah ditentukan pada suatu lingkungan belajar.

\section{Komponen Muatan Lokal}

1. Ruang Lingkup

a) Lingkup keadaan dan kebutuhan daerah.

Keadaan daerah adalah segala sesuatu yang terdapat di daerah tertentu yang pada dasarnya berkaitan dengan lingkungan alam, lingkungan sosial ekonomi, dan lingkungan sosial budaya.

Kebutuhan daerah adalah segala sesuatu yang diperlukan oleh masyarakat di suatu daerah, khususnya untuk kelangsungan hidup dan peningkatan taraf kehidupan masyarakat tersebut, yang disesuaikan dengan arah perkembangan daerah serta potensi daerah yang bersangkutan. Kebutuhan daerah tersebut adalah seperti kebutuhan untuk:

1) Melestarikan dan mengembangkan kebudayaan daerah;

2) Meningkatkan kemampuan dan keterampilan di bidang tertentu sesuai dengan keadaan perekonomian daerah;

3) Meningkatkan penguasaan Bahasa Inggris untuk keperluan peserta didik dan untuk mendukung pengembangan potensi daerah, seperti potensi pariwisata; dan

4) Meningkatkan kemampuan berwirausaha.

b) Lingkup isi/jenis muatan lokal. 
Lingkup isi/jenis muatan lokal dapat berupa: bahasa daerah, bahasa Inggris, kesenian daerah, keterampilan dan kerajinan daerah, adat istiadat, dan pengetahuan tentang berbagai ciri khas lingkungan alam sekitar, serta hal-hal yang dianggap perlu untuk pengembangan potensi daerah yang bersangkutan.

2. Pengembangan Muatan Lokal Pada Kurikulum 2013

Muatan lokal, sebagaimana dimaksud dalam Penjelasan Atas Undangundang Nomor 20 Tahun 2003 tentang Sistem Pendidikan Nasional, merupakan bahan kajian yang dimaksudkan untuk membentuk pemahaman peserta didik terhadap potensi di daerah tempat tinggalnya. Dalam Pasal $77 \mathrm{~N}$ Peraturan Pemerintah Nomor 32 Tahun 2013 tentang Perubahan Atas Peraturan Pemerintah Nomor 19 Tahun 2005 tentang Standar Nasional dinyatakan bahwa : (1) Muatan lokal untuk setiap satuan pendidikan berisi muatan dan proses pembelajaran tentang potensi dan keunikan lokal; (2) Muatan lokal dikembangkan dan dilaksanakan pada setiap satuan pendidikan.

Selanjutnya, dalam Pasal 77P antara lain dinyatakan bahwa : (1) Pemerintah daerah provinsi melakukan koordinasi dan supervisi pengelolaan muatan lokal pada pendidikan menengah; (2) Pemerintah daerah kabupaten/kota melakukan koordinasi dan supervisi pengelolaan muatan lokal pada pendidikan dasar; (3) Pengelolaan muatan lokal meliputi penyiapan, penyusunan, dan evaluasi terhadap dokumen muatan lokal, buku teks pelajaran, dan buku panduan guru; dan (4) Dalam hal seluruh kabupaten/kota pada 1 (satu) provinsi sepakat menetapkan 1 (satu) muatan lokal yang sama, koordinasi dan supervisi pengelolaan kurikulum pada pendidikan dasar dilakukan oleh pemerintah daerah provinsi.

Muatan lokal sebagai bahan kajian yang membentuk pemahaman terhadap potensi di daerah tempat tinggalnya bermanfaat untuk memberikan bekal sikap, pengetahuan, dan keterampilan kepada peserta didik.

3. Mekanisme Pengembangan Dan Pelaksanaan

a) Tahapan Pengembangan Muatan Lokal

1) Melakukan identifikasi dan analisis konteks kurikulum.

Identifikasi konteks kurikulum meliputi analisis ciri khas, potensi, keunggulan, kearifan lokal, dan kebutuhan/tuntutan daerah. Metode identifikasi dan analisis disesuaikan dengan kemampuan tim.

2) Menentukan jenis muatan lokal yang akan dikembangkan.

Jenis muatan lokal meliputi empat rumpun muatan lokal yang merupakan persinggungan antara budaya lokal (dimensi sosio-budayapolitik), kewirausahaan, pra-vokasional (dimensi ekonomi), pendidikan lingkungan, dan kekhususan lokal lainnya (dimensi fisik).

3) Menentukan bahan kajian muatan lokal

Kegiatan ini pada dasarnya untuk mendata dan mengkaji berbagai kemungkinan muatan lokal yang dapat diangkat sebagai bahan kajian sesuai dengan dengan keadaan dan kebutuhan satuan pendidikan.

4) Rambu-Rambu Pengembangan Muatan Lokal

a) Satuan pendidikan yang mampu mengembangkan standar kompetensi dan kompetensi dasar beserta silabusnya dapat melaksanakan mata pelajaran muatan lokal. Apabila satuan pendidikan belum mampu mengembangkan standar kompetensi dan kompetensi dasar beserta silabusnya, maka satuan pendidikan dapat melaksanakan muatan lokal 
berdasarkan kegiatan-kegiatan yang direncanakan oleh satuan pendidikan, atau dapat meminta bantuan kepada satuan pendidikan terdekat yang masih dalam satu daerahnya.

b) Bahan kajian disesuaikan dengan tingkat perkembangan peserta didik yang mencakup perkembangan pengetahuan dan cara berpikir, emosional, dan sosial peserta didik. Pembelajaran diatur agar tidak memberatkan peserta didik dan tidak mengganggu penguasaan kurikulum nasional.

c) Program pengajaran dikembangkan dengan melihat kedekatannya dengan peserta didik yang meliputi kedekatan secara fisik dan secara psikis. Dekat secara fisik berarti bahwa terdapat dalam lingkungan tempat tinggal dan sekolah peserta didik, sedangkan dekat secara psikis berarti bahwa bahan kajian tersebut mudah dipahami oleh kemampuan berpikir dan mencerna informasi sesuai dengan usia peserta didik. Untuk itu, bahan pengajaran perlu disusun berdasarkan prinsip belajar yaitu: (1) bertitik tolak dari hal-hal konkret ke abstrak; (2) dikembangkan dari yang diketahui ke yang belum diketahui; (3) dari pengalaman lama ke pengalaman baru; (4) dari yang mudah/sederhana ke yang lebih sukar/rumit. Selain itu, bahan kajian/pelajaran diharapkan bermakna bagi peserta didik yaitu bermanfaat karena dapat membantu peserta didik dalam kehidupan sehari-hari.

d) Bahan kajian/pelajaran diharapkan dapat memberikan keluwesan bagi guru dalam memilih metode mengajar dan sumber belajar seperti buku dan nara sumber. Dalam kaitan dengan sumber belajar, guru diharapkan dapat mengembangkan sumber belajar yang sesuai dengan memanfaatkan potensi di lingkungan satuan pendidikan, misalnya dengan memanfaatkan tanah/kebun satuan pendidikan, meminta bantuan dari instansi terkait atau dunia usaha/industri (lapangan kerja) atau tokoh-tokoh masyarakat. Selain itu, guru diharapkan dapat memilih dan menggunakan strategi yang melibatkan peserta didik aktif dalam proses belajar mengajar, baik secara mental, fisik, maupun sosial.

e) Bahan kajian muatan lokal yang diajarkan harus bersifat utuh dalam arti mengacu kepada suatu tujuan pengajaran yang jelas dan memberi makna kepada peserta didik. Namun demikian bahan kajian muatan lokal tertentu tidak harus secara terus-menerus diajarkan mulai dari kelas I sampai dengan kelas VI, atau dari kelas VII sampai dengan kelas IX, atau dari kelas X sampai dengan kelas XII. Bahan kajian muatan lokal juga dapat disusun dan diajarkan hanya dalam jangka waktu satu semester, dua semester, atau satu tahun ajaran.

f) Alokasi waktu untuk bahan kajian/pelajaran muatan lokal perlu memperhatikan jumlah hari/minggu dan minggu efektif untuk mata pelajaran muatan lokal pada setiap semester.

5) Langkah Pelaksanaan Muatan Lokal

a) Muatan lokal diajarkan pada setiap jenjang kelas mulai dari tingkat pra satuan pendidikan hingga satuan pendidikan menengah. Khusus pada jenjang pra satuan pendidikan, muatan lokal tidak berbentuk sebagai mata pelajaran. 
b) Muatan lokal dilaksanakan sebagai mata pelajaran tersendiri dan/atau bahan kajian yang dipadukan ke dalam mata pelajaran lain dan/atau pengembangan diri.

c) Alokasi waktu adalah 2 jam/minggu jika muatan lokal berupa mata pelajaran khusus muatan lokal.

d) Muatan lokal dilaksanakan selama satu semester atau satu tahun atau bahkan selama tiga tahun.

e) Proses pembelajaran muatan lokal mencakup empat aspek (kognitif, afektif, psikomotor, dan action).

f) Penilaian pembelajaran muatan lokal mengutamakan unjuk kerja, produk, dan portofolio.

g) Satuan pendidikan dapat menentukan satu atau lebih jenis bahan kajian mata pelajaran muatan lokal.

h) Penyelenggaraan muatan lokal disesuaikan dengan potensi dan karakteristik satuan pendidikan.

i) Satuan pendidikan yang tidak memiliki tenaga khusus untuk muatan lokal dapat bekerja sama atau menggunakan tenaga dengan pihak lain.

\section{Media Pembelajaran}

Media Pembelajaran merupakan sesuatu hal yang dapat digunakan pada saat proses belajar mengajar. Beberapa ahli mendefinisikan pengertian media menurut pendapatnya masing-masing. Anitah, (2009:1) menjelaskan bahwa, "Kata media berasal dari bahasa latin, yang merupakan bentuk jamak dari kata medium, yang berarti sesuatu yang terletak di tengah (antara dua pihak atau kutub) atau suatu alat. Media juga dapat diartikan sebagai perantara atau penghubung antara dua pihak, yaitu antara sumber pesan dengan penerima pesan atau informasi. Oleh karena itu, media pembelajaran berarti sesuatu yang mengantarkan pesan pembelajaran antara pemberi pesan kepada penerima pesan"

\section{Media Audio Visual}

Asyhar, Rayanda. 2011, mendefinisikan bahwa media audio visual adalah jenis media yang digunakan dalam kegiatan pembelajaran dengan melibatkan pendengaran dan penglihatan sekaligus dalam satu proses atau kegiatan. Pesan dan informasi yang dapat disalurkan melalui media ini dapat berupa pesan verbal dan nonverbal yang mengandalkan baik penglihatan maupun pendengaran. Beberapa contoh media audio visual adalah film, video, program TV dan lain-lain.

Berdasarkan penjelasan di atas dapat disimpulkan bahwa media audio visual merupakan media yang dapat digunakan dalam kegiatan pembelajaran dengan melibatka pendengaran dan penglihatan sekaligus dalam satu proses atau kegiatan. Contoh media audio visual adalah film, video, program TV, slide suara (sound slide) dan lain-lain (Atmarita \& Syarifuddin, 2021).

\section{Langkah-langkah Menggunakan Media Audio Visual Upacara Adat Daerah Bima}

Media pembelajaran audio visual Media Audio Visual Upacara Adat Daerah Bima memiliki langkah-langkah dalam penggunaannya seperti halnya media pembelajaran lainnya. Langkah- langkah pembelajaran menggunakan media audio visual adalah sebagai berikut. 
1. Persiapan, yakni mempersiapan pemilihan video yang diunduh dari internet yang berkaitan dengan berbagai upacara adat daerahh Bima selanjutnya dirancang dalam RPP.

2. Pelaksanaan/Penyajian, dilaksanakan sesuai dengan RPP yang telah diancang.

3. Tindak lanjut

\section{METODE PENELITIAN}

\section{Subyek Penelitian}

Subyek perbaikan adalah siswa-siswi Kelas X IPS-4 Semester I SMAN 4 Kota Bima dengan jumlah siswa 31 terdiri dari 15 orang laki-laki dan 16 orang perempuan. Adapun karakteristik siswa rata-rata memiliki intake, kemampuan akademik yang sedang. Kreativitas dan motivasi belajar siswa rata-rata sedang.

Faktor Yang diteliti. Adapun faktor-faktor yang akan diteliti adalah:

a. Hasil belajar siswa, sejauh mana hasil belajar pada pembelajaran Mulok materi materi Upacara Adat Daerah Bima di Kelas X IPS-4 Semester I SMAN 4 Kota Bima tahun pelajaran 2020/2021.

b. Kinerja guru, diteliti sejauh mana ketuntasan guru dalam perencanaan dan pelaksanaan pembelajaran sesuai dengan instrument yang telah ditetapkan yakni menggunakan APKG I dan APKG II.

\section{Tempat Penelitian}

Penelitian Perbaikan Pembelajaran ini dilakukan di Kelas X IPS-4 Semester I SMAN 4 Kota Bima.

\section{Waktu Penelitian}

Perbaikan dilaksanakan dalam 2 (dua) siklus. Siklus I dari tanggal 13 Agustus 2020 sampai dengan 23 September 2020 dan siklus II dilaksanakan tanggal 02 Oktober 2020 sampai dengan 15 November 2020.

\section{Pihak yang Membantu}

Adapun pihak-pihak yang membantu dalam penelitian ini adalah:

a) Kepala SMAN 4 Kota Bima

b) Guru teman sejawat, sebagai observer dalam pelaksanaan penelitian

c) Siswa-siswi SMAN 4 Kota Bima

\section{Desain Prosedur Perbaikan Pembelajaran}

\section{Gambaran Umum Perbaikan}

a. Data dan Cara Pengambilannya

1) Sumber data: sumber data perbaikan ini adalah seluruh siswa Kelas X IPS-4 Semester I SMAN 4 Kota Bima.

2) Jenis data :

a) Data kualitatif terdiri dari:

(1) Teacher's note (Rancangan Pembelajaran)

(2) Data hasil observasi pelaksanaan pembelajaran dan activitas siswa.

(3) Jurnal tim peneliti

b) Data Kuantitatif

(1) Nilai pos tes 
(2) Nilai kinerja guru

(3) Teknik Pengambilan data

(a) Data kualitatif diambil dari teacher's note (rencana pembelajaran) yang dibuat peneliti.

(b) Data tentang refleksi diri diambil dari jurnal yang dibuat oleh peneliti.

(c) Data kuantitatif diambil dari skor nilai tes siswa.

b. Indikator Kinerja

a) Aktivitas siswa dalam proses pembelajaran Mulok.

b) Hasil belajar siswa, rata-rata nilai post test untuk pada pembelajaran Mulok $\geq 70$ dengan prosentase ketuntasan belajar siswa $\geq 83 \%$

c) Kinerja Guru, APKG I untuk perencanaan pembelajaran $\geq 90.00$.

d) Kinerja Guru, APKG II untuk pelaksanaan pembelajaran $\geq 90.00$.

c. Intrumen Perbaikan

a) Instrumen perbaikan berupa test.

b) Lembar observasi kinerja guru.

\section{Deskripsi Per-siklus/Desain Perbaikan}

a. Siklus Perbaikan

Siklus perbaikan dilaksanakan dalam dua siklus. siklus. Tiap siklus terdiri dari 4 (empat) tahapan utama yakni: perencanaan; penerapan tindakan; observasi dan refleksi. Hasil refleksi akan menentukan apakah PTK dalam siklus tersebut berhasil atau belum berhasil. Jika belum berhasil maka akan dilanjutkan pada siklus berikutnya.

b. Rincian Prosedur Perbaikan

1) Siklus Pertama

a) Perencanaan adalah:

Dalam tahap perencanaan ini kegiatan pokok yang dilakukan

(1) Menyusun jadwal perbaikan

(2) Menyiapkan instrument pengamatan perbaikan

(3) Menyusun Rencana Pembelajaran (RPP)

(4) Mempersiapkan materi pembelajaran

b) Penerapan Tindakan

Melaksanakan Pembelajaran dengan mengacu pada penataan Skenario Pembelajaran.

c) Observasi

Dalam observasi ini peneliti mengobservasi seluruh rangkaian kegiatan proses pembelajaran apakah dapat berjalan seperti yang direncanakan atau tidak. Di sini peneliti dan observer melakukan pencatatan item-item kegiatan yang secara signifikan mempengaruhi proses pembelajaran, baik yang berpengaruh positif maupun negative. Obyek observasi meliputi aktivitas guru, siswa, serta efektivitas media yang digunakan. Observer juga menggunakan lembar observasi dengan mengisi item-item butir observasi yang telah dipersiapkan.

Dalam observasi ini akan menentukan ketercapaian indikatorindikator utama yang menjadi tolok ukur keberhasilan perbaikan ini khususnya kemapuan membaca dan menulis siswa dan kemampuan guru 
dalam melaksanakan dan menyelesaikan Rencana Pembelajaran (RPP) dengan langkah pembelajaran Mulok yang mengacu pada kombinasi media audio visual .

d) Refleksi

Dengan menganalisa hasil observasi maka dilakukan refleksi, merenungkan kembali apa yang telah peneliti lakukan. Kegiatan refleksi ini bertujuan untuk:

1. Mengetahui dan menyimpulkan langkah-langkah manakah yang dapat berjalan seperti yang direncanakan.

2. Mengetahui dan menyimpulkan langkah-langkah manakah yang tidak dapat berjalan seperti yang direncanakan.

3. Mengetahui dan menimpulkan indikator manakah yang sudah tercapai dan indikator mana yang belum tercapai.

4. Yang paling penting adalah menentukan perbaikan pembelajaran pada siklus selanjutnya (siklus kedua). Perbaikan ini dapat mencakup aspekaspek:
a. Pengelolaan kelas
b. Penataan skenario pembelajaran
c. Desain tes
d. Desain media pembelajaran
e. Dan temuan-temuan lainnya.

\section{Siklus Kedua}

Kegiatan pada siklus kedua merupakan rangkaian kegiatan yang tidak terpisahkan dengan kegiatan siklus pertama. Langkah-langkah kegiatan siklus kedua tidak jauh berbeda dengan siklus pertama. Disini langkah-langkah direncanakan dan dilaksanakan berdasarkan hsil refleksi penerapan tindakan siklus pertama.
a. Perencanaan
b. Penerapan tindakan
c. Observasi dan
d. Refleksi

\section{Teknik Pengumpulan dan Analisis Data}

\section{Teknik Pengumpulan Data}

Teknik pengumpulan data kualitatif diambil melalui dokumentasi dan tes. Sedangkan pengumpulan data kuantitatif diambil melalui tes.Penjelasan tehnik pengumpulan data sebagai berikut:

\section{a) Dokumentasi}

Metode dokumentasi yaitu mencari data mengenai hal-hal atau variable yang berupa catatan lapangan, transkip, buku, surat kabar, majalah, prasasti, notulen rapat, agenda, dan sebagainya (Arikunto.2002:206). Studi dokumentasi dilakukan untuk memperkuat data yang di peroleh dalam observasi. Dokumen yang di gunakan dalam penelitian ini berupa LKS dan daftar nilai siswa.

b) Tes

Tes adalah serentetan pertanyaan atau latihan serta alat lain yang digunakan untuk mengukur keterampilan, pengetahuan inteligensi, kemampuan atau bakat yang 
dimiliki oleh individu atau kelompok (Arikunto.2002:127). Tes dapat digunakan untuk mengukur kemampuan dasar dan pencapaian atau hasil belajar. Tes diberikan kepada siswa untuk mengetahui kemampuan kognitif siswa. Tes ini dikerjakan siswa secara individual setelah mempelajari suatu materi. Tes ini dilaksanakan pada saat proses pembelajaran melalui LKS dan tes akhir pembelajaran pada siklus I, siklus II.

\section{Teknik Analisis Data}

Berikut teknik dalam mengolah data yang digunakan untuk menilai aktivitas belajar siswa pada metode pembelajaran modelling, hasil belajar siswa, dan performansi guru.

\section{Hasil belajar Siswa}

a) Menentukan Nilai Akhir Siswa

Untuk menentukan nilai akhir hasil belajar yang diperoleh masing- masing siswa yaitu dengan cara:

Keterangan:

$$
N A=\frac{S P}{S M} \times 100 \%
$$

$N A=$ Nilai Akhir

$S P=$ Skor Perolehan $S M=$ Skor Maksimal

b) Menentukan Rata-rata Kelas

Rata-rata kelas dapat dihitung dengan cara;

$$
M=\sum \frac{x}{n}
$$

Keterangan:

$\sum X=$ jumlah nilai yang diperoleh siswa

$\sum n=$ jumlah siswa

M = rata-rata kelas (Sudjana 2010: 125)

c) Menentukan Tuntas Belajar Klasikal:

$$
T B K=\frac{\text { Jumlah siswa yang memenuhi KKM }}{\text { Jumlah siwa keseluruhan }} \times 100 \%
$$

Keterangan :

TBK : Tuntas belajar klasikal

\section{Instrumen Penelitian}

a) Hasil belajar

Instrumen yang digunakan untuk mengukur hasil belajar dengan menggunakan tes.

b) Performansi Guru

Ada dua kategori yang diamati selama penelitian dalam kaitannya dengan performansi guru, yaitu pengamatan dalam perencanaan (APKG I) dan pelaksanaan pembelajaran (APKG II) yang selanjutnya dikonversi dalam angka rentangan 0-100. 


\section{Indikator Keberhasilan}

Penelitian tindakan kelas ini direncanakan dalam dua siklus tindakan. Indikator keberhasilan penelitian dapat dilihat melalui pengamatan terhadap hasil belajar, aktivitas belajar, dan performansi guru. Indikator keberhasilan pembelajaran dengan pengggunaan media Audio Visual dijabarkan sebagai berikut:

a. Hasil belajar Siswa

Hasil belajar siswa telah mencapai indikator keberhasilan apabila nilai siswa di atas $\mathrm{KKM} \geq 70 \%$ dengan $\mathrm{KKM} 70$, persentase tuntas belajar klasikal sekurang-kurangnya $83 \%$ (minimal $70 \%$ siswa yang memperoleh skor $\geq 70)$ dan nilai siswa meningkat dari siklus I.

b. Performansi Guru

Nilai performansi guru dapat dilihat berdasarkan lembar pengamatan APKG. APKG terdiri dari APKG I berupa pengamatan terhadap perencanaan pembelajaran dan APKG II berupa pengamatan terhadap pelaksanaan pembelajaran. Skor performansi guru minimal dalam perencanaan pembelajaran, APKG 1 minimal 90. pelakanaan pembelajaran, APKG 2 minimal 90.

\section{HASIL DAN PEMBAHASAN}

\section{Deskripsi Hasil Penelitian Perbaikan Pembelajaran}

\section{Hasil Perbaikan}

\section{a. Perencanaan}

RPP yang disusun sesuai dengan tuntutan pendekatan saitifik dengan model pembelajaran discovery learning. RPP yang disusun dengan menggunakan media audio visual bertujuan mendukung upaya peningkatan aktivitas, motivasi belajar siswa guna meningkatkan hasil belajar siswa. Media yang digunakan disiapkan guru akan tetapi siswa juga diberi kesempatan untuk memilih, mencari media yang sesuai secara online sesuai dengan minat siswa. Langkah ini direncanakan secara bertahap sehingga sehingga penggunaan media audio visual dengan model pembelajaran discovery learning dalam RPP memiliki nilai keunggulan-keunggulan seperti yang direncanakan.

b. Pelaksanaan Tindakan

Pelaksanaan pembelajaran siklus I pada awal-awal berjalan dengan baik, dimana seluruh siswa aktif. Pelaksanaan pembelajaran terhambat ketika siswa diharuskan mengerjakan atau melakukan sesuatu, baik secara lisan: mengajukan pertanyaan, beerdiskusi, mempresentasikan hasil kerja maupun secara tertulis: merangkum, mengerjakan soal dan sebagainya. Meskipun tingkat aktivitas meningkat dari waktu.

Hasil belajar dari hasil pos tes individual dan kinerja guru siklus I dilanjutkan data hasil belajar dan kinerja guru siklus II sebagai berikut:

Tabel 1. Nilai Hasil belajar Siklus I dan Siklus II

\begin{tabular}{|c|c|c|c|c|c|}
\hline \multicolumn{2}{|c|}{ Pra Siklus } & \multicolumn{2}{c|}{ Siklus I } & \multicolumn{2}{c|}{ Siklus II } \\
\hline $\begin{array}{c}\text { Rata- } \\
\text { Rata }\end{array}$ & $\%$ & Rata- & $\%$ & Rata- & $\%$ \\
Ketercapaian & $\begin{array}{c}\text { Rata } \\
\text { Ketercapaian }\end{array}$ & $\begin{array}{c}\text { Rata } \\
\text { Ketercapaian }\end{array}$ \\
\hline 64.00 & $68.00 \%$ & 68.12 & $73.00 \%$ & 77.00 & $85.00 \%$ \\
\hline
\end{tabular}


Tabel 2. Nilai Kinerja Guru Siklus I dan Siklus II

\begin{tabular}{|c|c|c|c|c|c|}
\hline \multicolumn{2}{|c|}{ Pra Siklus } & \multicolumn{2}{c|}{ Siklus I } & \multicolumn{2}{c|}{ Siklus II } \\
\hline APKG I & $\begin{array}{c}\text { APKG } \\
\text { II }\end{array}$ & APKG I & $\begin{array}{c}\text { APKG } \\
\text { II }\end{array}$ & APKG I & $\begin{array}{c}\text { APKG } \\
\text { II }\end{array}$ \\
\hline 89.00 & 88.00 & 89.45 & 88.45 & 91.00 & 90.77 \\
\hline
\end{tabular}

c. Observasi

Kegiatan observasi dilakukan oleh observer mengamati jalannya proses pembelajaran. Dalam observasi ini observer menggunakan lembar observasi dimana dalam format lembar observasi mengacu pada instrumen penilaian kinerja guru APKG I untuk perencanaan pembelajaran dan APKG II untuk pelaksanaan pembelajaran. Kompetensi guru dalam perencanaan dan melaksanakan perencanaan dan pelaksanaan pembelajaran diberikan skor dengan rentangan 1-5 dan hasil akhir dihitung dengan skor maksimal 5.

\section{Pembahasan Hasil Penelitian Perbaikan Pembelajaran \\ Pembahasan Siklus I}

a. Hasil belajar

Hasil pos tes siklus I diatas menunjukkan bahwa hasil belajar siswa Mulok ratarata 68.12. Meskipun nilai rata-rata ini telah mengalami peningkatan dibanding sebelum diadakan perbaikan $(+4.12)$, tetapi nilai ini belum memenuhi indikator kinerja yang ditetapkan yakni rata-rata $\geq 70.00$. Persentase ketuntasan $73.00 \%$ meningkat sebelum diadakan perbaikan $(+5.00)$, Persentase ini masih dibawah indikator kinerja yakni $\geq 83.00 \%$. Dari sisi prestasi belajar siklus I (pertama) belum berhasil.

b. Kinerja guru

Skor kinerja guru, kompetensi guru dalam perencanaan (APKG I) siklus I 89.45 nilai ini telah mengalami peningkatan sebelum diadakan perbaikan $(+0.45)$ dan skor kinerja guru dalam pelaksanaan pembelajaran yang mendidik (APKG II) siklus I 88.45 meskipun nilai ini telah mengalami peningkatan dibanding sebelum diadakan perbaikan (+0.45). Dengan demikian dari sisi kinerja guru siklus I belum mencapai indikator kinerja yang ditetapkan yakni APKG I dan APKG II yakni $\geq 90.00$.

c. Refleksi

RPP telah siklus I sudah baik, perlu perbaikan sedikit pada langkah pembelajaran inti dalam kerja kelompok. Yang perlu perbaikan pada pelaksanaan pembelajaran di kelas khususnya:

- Pada kegiatan yang mengharuskan siswa mengerjakan sesuatu, aktivtias siswa tidak optimal. Terdapat siswa yang pasif, tidak mengerjakan tugas yang diberikan. Guru perlu memotivasi siswa, membimbing siswa, ataupun dengan mengarahkan siswa yang pasif untuk melakukan tugasnya baik langsung dimonitor oleh guru maupun didelegasikan oleh siswa lain sebagai tutor sebaya.

- Dalam kerja kelompok masih terdapat siswa yang pasif, tidak memberikan kontribusi pada kelompoknya. Demikian juga terdapat bebeerapa siswa yang berupaya mendominasi kerja kelompk sehingga siswa lain tidak ada kesempatan. Guru perlu membimbing kerja kolaborasi dimana tiap anggota kelompok berkontribusi dalam kelompok serta saling menghargai anggota kelomponya. 


\section{Pembahasan Siklus Kedua (II)}

\section{a. Hasil perbaikan}

\section{1) Perencanaan}

Perencanaan siklus II dilakukan perbaikan pada langkah-langkah dalam kegiatan inti menyesuaikan dengan hasil refleksi siklus I. RPP tidak banyak mengalami perubahan yang substansial.

2) Penerapan Tindakan

Belum tercapainya indikator kinerja siklus I dikarenakan langkah-langkah kegiatan inti belum seluruhnya berjalan seperti yang direncanakan. Adapun pelaksanaan pembelajaran siklus II, mempertahankan dan meningkatkan pelaksanaan pembelajaran siklus I yang sudah berjalan dengan baik dan memperbaiki langkahpembelajaran siklus I yang belum sesuai RPP yakni pada langkah:

- Pada kegiatan yang mengharuskan siswa mengerjakan sesuatu, aktivtias siswa sudah optimal. Siswa yang pasif, tidak mengerjakan tugas yang diberikan, guru mampu memotivasi siswa, membimbing siswa, ataupun dengan mengarahkan siswa yang pasif untuk melakukan tugasnya baik langsung dimonitor oleh guru maupun didelegasikan oleh siswa lain sebagai tutor sebaya, sehingga aktivitas siklus II ini tidak terjadi kesenjangan yang meencolok antar siswa.

- Dalam kerja kelompok seluruh sisiwa aktif, sesuai dengan kompetensinya setiap siswa memberikan kontribusi pada kelompoknya. Dominasi siswa tertentu pada saat kerja kelompok telah diminimalisir. Guru telah membimbing siswa untuk kerja kolaborasi dimana tiap anggota kelompok berkontribusi dalam kelompok serta saling menghargai anggota kelomponya.

Seluruh langkah yang harus diperbaiki telah dilaksanakan dengan baik yang telah ditetapkan sesuai RPP siklus II yang direncanakan.

3) Observasi

Dalam kegiatan ini langkah-langkah tidah jauh berbeda dengan yang dilaksanakan pada siklus I. Untuk hasil belajar menggunakan rubrik penilaian, guna mengetahui hasil belajar siswa dari hasil penilaian menggunakan audio visual . Observer menggunakan lembar observasi kinerja guru untuk mengamati seluruh pelaksanaan proses pembelajaran.

a) Hasil belajar

Hasil pos tes siklus II diatas menunjukkan bahwa hasil belajar siswa Mulok rata-rata 77.00. Nilai rata-rata ini telah mengalami peningkatan dibanding siklus I (+8.88) dengan persentase ketuntasan $85.00 \%$, mengalami peningkatan dibanding siklus I (+12.00). Persentase ini telah memenuhi indikator kinerja yakni $\geq 83.00 \%$. Dengan demikian pada siklus II ini telah berhasil mencapai indikator yang ditetapkan yakni rata-rata $\geq 70.00$ dan persentase ketuntasan $\geq 83.00 \%$. Dari sisi prestasi belajar siklus II (kedua) telah berhasil.

b) Kinerja guru

Skor kinerja guru menunjukkan bahwa skor ketuntasan guru dalam perencanaan pembelajaran siklus II APKG I 91.00 nilai ini telah mengalami peningkatan dibandingkan siklus I (+1.55) dan skor kinerja guru dalam pelaksanaan pembelajaran APKG II siklus II 90.77 dibanding siklus I mengalami peningkatan (+2.32). Dengan perbaikan proses pembelajaran 
berhasil memenuhi indikator kinerja yang ditetapkan yakni perencanaan APKG I dan pelaksanaan APKG II yakni $\geq 90.00$.

4) Refleksi

Penggunaan audio visual secara signifikan berpengaruh pada proses maupun hasil penilaian pembelajaran yang lebih komprehensif. Keberhasilan ditunjukkan dengan peningkatn aktivitas, kreativitas dan motivasi belajar, kerjasama sinergi antar siswa dalam menyelesasikan tugas kelompok.

Memperkuat pendapat Arsyad (2011), yang menyatakan bahwa media audio visual memiliki kelebihan:

a) Film dan vidio dapat melengkapi pengalaman dasar siswa.

b) Film dan vidio dapat menggambarkan suatu proses secara tepat yang dapat disaksikan secara berulang-ulang jika perlu.

c) Di samping mendorong dan meningkatkan motivasi film dan video menanamkan sikap-sikap dan segi afektif lainnya.

d) Film dan video yang mengandung nilai-nilai positif dapat mengundang pemikiran dan pembahasan dalam kelompok siswa.

e) Film dan video dapat menyajikan peristiwa yang berbahaya jika dilihat secara langsung.

f) Film dan video dapat ditunjukkan kepada kelompok besar atau kelompok kecil, kelompok yang heterogen maupun homogen maupun perorangan.

g) Film yang dalam kecepatan normal memakan waktu satu minggu dapat ditampilkan dalam satu atau dua menit.

Penggunaan Kombinasi media gamabar dan audio visual, yang peneliti lakukan, dengan perencanaan yang matang pelaksanaan pembelajaran yang konsisten berhasil mencapai indikator kinerja yang ditetapkan. Dengan demikian penelitian perbaikan pembelajaran Mulok materi materi Upacara Adat Daerah Bima dinyatakan berhasil pada siklus II dan tidak perlu dilanjutkan ke siklus III.

\section{KESIMPULAN}

Kesimpulan dari penelitian ini antara lain: 1) Penggunaan media audio visual dapat meningkatkan hasil belajar siswa pembelajaran Mulok materi materi Upacara Adat Daerah Bima di Kelas X IPS-4 Semester I SMAN 4 Kota Bima tahun pelajaran 2020/2021; 2) Penggunaan media audio visual dapat memacu kinerja guru baik pada perencanaan pembelajaran maupun pelaksanaan pembelajaran Mulok materi Upacara Adat Daerah Bima SMAN 4 Kota Bima di Kelas X IPS-4 semester I tahun pelajaran 2020/2021.

Saran dan tindak lanjut dari penelitian ini adalah: 1) Kepada guru disarankan untuk menggunakan media audio visual agar pembelajaran mencapai hasil yang optimal; 2) Kepada guru disarankan untuk mengembangakan menggunakan media audio visual untuk materi pembelajaraan yang lain baik pada pembelajaran Mulok maupun mata pelajaran lainnya; dan 3) Kepada sekolah, instansi terkait disarankan untuk dapat menyediakan fasilitas penunjang proses pembelajaran efektvitas pelaksanaan Kurikulum 2013 baik pada perencanaan, pelaksanaan maupun penilaian pembelajaran. 


\section{DAFTAR PUSTAKA}

Ariyana, Yoki, et.al., (2018). Buku Pegangan Pembelajaran Berorientasi padaKeterampilan Berpikir Tingkat Tinggi, Jakarta: Dirjen GTKKemendikbud.

Asyhar, R. (2011). Kreatif mengembangkan Media Pembelajaran. Jakarta: Gaung Persada Press.

Arsyad, Azhar. (2011). Media Pembelajaran. Jakarta: PT. Raja Grafindo Persada.

Ahmadi, Abu dan Munawar Sholeh. (2005). Psikologi Perkembangan. Jakarta: Rineka Cipta.

Alma, Buchari, dkk. (2010). Pembelajaran Studi Sosial.Bandung : CV Alfabeta.

Agus Suprijono. (2011). Model-Model Pembelajaran. Jakarta: Gramedia Pustaka Jaya.

Anitah, Sri. (2009). Media Pembelajaran.Surakarta: Panitia Sertifikasi GuruRayon13 FKIP UNS Surakarta.

Achmad Rifa'I dan Chatarina Tri Anni. (2009), Psikologi pendidikan.Semarang Unnes Press.

Achmad Sugandi, dkk. (2007). Teori Pembelajaran.Semarang: UPT MKK Universitas Negeri Semarang.

Anni, Catharina T. (2007). Psikologi Belajar. Semarang: UNNES.

Atmarita, A., \& Syarifuddin, S. (2021). Visual Processing Assessment on Children: A Pilot Study. Jurnal Pendidikan dan Pembelajaran Indonesia (JPPI), 1(1), 1-9.

Busono, G. A. (2016). Pengaruh Sistem Pelatihan Dan Pengembangan Karyawan Terhadap Kinerja Karyawan Pt. Persada Sawit Mas (PSM) Kecamatan Pampangan Kabupaten Ogan Komering Ilir.Muqtashid,1(1), 81-114.

Desmita. (2010). Psikologi Perkembangan.Bandung: PT. Remaja Rosdakarya.

Depdiknas. (2003). Undang-undang RI No.20 tahun 2003.tentang sistem pendidikan nasional.

Elliot, John. (1982). "Developing Hypothesis abot Classroom from Teachers Practical Constructs : an Account of the Work of the Ford Teaching Project". The Action Research Reader Geelong Vcitoria : Deakin University.

Hardjodipuro, Siswojo. (1997). Action Research Sintesis Teoretik,Jakarta, IKIP Jakarta.

Hadi,S., Tukiran, T., \& Yuwono, B. (2009). Pengaruh Supervisi Akademik, Kompetensi Guru dan Kedisiplinan Terhadap Kinerja Guru SMA Negeri 3 Slawi Kabupaten Tegal.Khazanah Pendidikan,2(1).

Hamalik, O., (2011), Proses Belajar Mengajar. Jakarta: Bumi Aksara.

Isjoni. (2010). Pembelajaran Kooperatif. Meningkatkan kecerdasan antar peserta didik. Yogyakarta : Pustaka Pelajar.

I.G.A.K. Wardani. (2019). Pemantapan Kemampuan Profesional. Jakarta: Universitas Terbuka KTSP SD/MI 2019.

@2021 JPPI (https://jurnal.bimaberilmu.com/index.php/jppi) 
Kartowagiran, B. (2011). Kinerja Guru Profesional (Guru Pasca Sertifikasi).Jurnal Cakrawala Pendidikan,3(3).

Kemdikbud. (2013). Permendikbud 81A tahun 2013 tentang Implementasi Kurikulum 2013. Jakarta: Kementrian Pendidikan dan Kebudayaan.

Kemendikbud .(2016). Permendikbud Nomor 22 Tahun 2016 Tentang Standar Proses Pendidikan Dan Menengah. Jakarta: Kemendikbud.

Kementerian Pendidikan Nasional. Direktorat Jenderal Peningkatan Mutu Pendidik dan Tenaga Kependidikan. 2010. Pedoman Pelaksanaan Penilaian Kinerja Guru(PK Guru). Jakarta. www.bermutuprofesi.org.

Kemendikbud. (2013). Permendikbud No.64 tentang Standar Isi Pendidikan Dasar dan Menengah. Jakarta: Kementerian Pendidikan dan Kebudayaan.

Kemendikbud. (2013). Permendikbud No.65 tentang Standar Proses Pendidikan Dasar dan Menengah. Jakarta: Kementerian Pendidikan dan Kebudayaan.

Permendikbud (2013). Peraturan menteri pendidikan dan Kebudayaan Nomor 66 tahun 2013 Tentang Standar Penilaian Pendidikan.

Minarsih, M. M. (2015). Analisis Pengaruh Kepemimpinan Transformasional, Moral Dan Komitmen Organisasi Terhadap Organizational Citizenship Behavior Dalam Meningkatkan Kinerja Guru Sekolah Dasar Swasta di Kecamatan Pedurungan Kota Semarang.Jurnal Ekonomi dan Bisnis Kontemporer,1(01).

Nuchiyah, Nunu.(2007). Pengaruh Kepemimpinan Kepala Sekolah dan Kinerja Mengajar Guru Terhadap Prestasi Belajar Siswa. Jurnal Pendidikan Dasar. Vol.5 no.7: $1-4$

Soeparwoto. (2007). Psikologi Perkembangan.Semarang: UPT UNNES PRESS.

Suyadi. (2010). Psikologi Belajar Anak Usia Dini. Yogyakarta : PEDAGOGIA.

Subana, M dan Sunarti, (1998). Strategi Belajar Mengajar Bahasa Indonesia.Bandung: Pustaka Setia.

Slameto. (2010). Belajar dan faktor-faktor yang Mempengaruhinya. Jakarta: PT. Rineka Cipta.

Siddiq, M. Djauhar, dkk. (2009). Pengembangan bahan Pembelajaran SD. Jakarta:Universitas Terbuka.

Saminanto. (2010). Model-model pembelajaran, Bandung : PT. Refika.

Santrock, J. W. (1998). Perkembangan Remaja. Jakarta: Erlangga.

Yusuf, Syamsu. (2011). Psikologi Perkembangan Anak dan Remaja. Bandung : PT. Remaja Rosdakarya. 